\title{
We Need to Talk about Cultural Studies
}

\section{JUSTIN O'CONNOR}

QUEENSLAND UNIVERSITY OF TECHNOLOGY

\begin{abstract}
Graeme Turner
What's Become of Cultural Studies
\end{abstract}

Sage, London, 2012

ISBN 9781849205849 (PB), 9781849205832 (HB)

RRP $£ 23.99$ (PB), $€ 68.00$ (HB)

Lawrence Grossberg

Cultural Studies in the Future Tense

Duke University Press, Durham, 2010

ISBN 9780822348306 (PB), 9780822348443 (HB)

RRP \$US25.95 (PB), \$US89.95 (HB)

Cultural Studies is in some sort of trouble. But is it a mid-life crisis or a terminal decline? What was often called 'British Cultural Studies' began life in the mid-sixties in a portacabin on the literal and metaphorical margins of the formally constituted disciplines of English and Sociology at the University of Birmingham. Like a garage 
band the hostility of the neighbours became a fond memory as it went on to conquer the world. It seemed to articulate a new kind of inter- and even anti-disciplinary intellectual program in tune with the zeitgeist of a proliferating popular culture. Looking back on the success story two new books suggest 1992 was a (hubristic) highpoint; they also suggest that cultural studies has since lost its way somewhat. Optimistic that cultural studies has a future, neither wants to suggest a lapse from the Golden Years; in fact, maybe the Golden Years are now part of the problem. Cultural studies is wrestling with its radical youth. Fiercely 'undisciplined'-as Turner describes it-it now has to face up to the challenge of putting down institutional roots if it is to ensure the long-term viability of its project. But what is that project? The problem is not just the general awareness of cultural theory by established disciplines-after the cultural turn we all do cultural studies! There is also a sense that the 'popular culture' with which cultural studies was so closely associated, and which gave it much of its radical charge, may no longer be where it's at.

Graeme Turner's is the shorter, less ambitious book-and more focused for that. His concerns are directly related to the position of cultural studies in the contemporary university, mostly the Anglophone sphere, though with an important chapter on Asia. As with Larry Grossberg-to whose current book he frequently refers-Turner is increasingly conscious of the proper limits of cultural studies as an intellectual project. Limits vis-à-vis other disciplines certainly, but also in relation to the university as a site of political intervention. Cultural studies was not some intrusion from the streets, a generation of popular cultural intellectuals ready to challenge the cloistered elites of high art and carefully corralled knowledge. It certainly brought in a concern with 'the media, popular culture and everyday life' (43) the study of which had been 'like an old car that someone had abandoned to rust in a vacant lot'. And its 'undiscipline' had seen it forage across intellectual fences and rummage through disciplinary lock-ups to find the concepts and the methods that would give full power to its new object. Turner is right to remind us of how annoyed these academic neighbors were at the time and is rightly incensed that cultural studies, having identified the unloved rust-bucket:

hopped in, hot-wired it and drove it away, took it to the body shop to be repaired and customized, only to find that when they took it out for a spin 
the previous owners chased them down the road, yelling out 'Hey, that's my car!' (35)

But the space for cultural studies was, in the end, a space opened within academia, albeit one whose scope and function were in rapid transformation.

Interdisciplinarity was, and continues to be, a crucial component of the project of cultural studies but this is not to be equated with resisting institutionalisation per $s e$. Turner is quite clear that if the cultural studies project is to survive then it needs to acknowledge and develop its institutional roots, and its best way of doing this is to establish itself as a discipline. On the one hand this is about an organisation of knowledge, methods, authorities, accreditation and so on. Turner has a very powerful chapter on teaching cultural studies and the responsibilities of academics to give proper disciplinary foundations to their students-for their career prospects and their future as informed citizens. On the other it is about having the institutional clout to command resources. Without this the danger is that cultural studies will simply serve other disciplines, providing the cultural bits on others' programs while having no home of its own.

Disciplines are very good mechanisms for reproducing themselves (after all, that is what they were designed to do), but there is good reason to think that the interdisciplines are not designed to do this very well at all. In most cases, the interdisciplinary enterprise is an interventionary one, tending towards a contingent institutional embodiment rather than a long-term program of development and selffashioning. (85)

Turner is aware of the tensions of turning an interdisciplinary program into a discipline; there are dangers but we have to live with them because the consequences of not doing so are worse. Cultural studies should continue to range across the disciplines, but it needs to acknowledge the specific protocols and contexts of the concepts and methods it borrows. No longer the ear-studded cultural studies guru in jeans pontificating on anything and everything as a cultural signifier; Turner and Grossberg want conceptual rigour, engaged empirical research, hard work and respect for disciplinary neighbours.

What is the cultural studies project? For Turner it is about 'the media, popular culture and everyday life', certainly, and sometimes the role of representation within these. Interdisciplinarity was crucial to the acquisition of the concepts that 
allowed it to accord full importance to its subject; but though an academic project it was not merely academic. Unlocking the disciplines meant asking the questions they did not want to ask. Cultural studies is a transformative political project, something he and Grossberg take pains to affirm. Turner endorses Jim McGuigan's recent description of cultural studies as 'critique in the public interest', and indeed it seems no longer an assault on the university (if it ever was such) but rather a desperate defence of the institutional context in which this critique was made possible. After many years battling for humanities funding from an Australian state apparatus hellbent on ploughing everything into research for the 'national [read: economic] interest', Turner knows what he is talking about. Cultural studies must become a discipline not only to secure its place within the university but also it seems to save the university. No longer are the stuffy cloisters to be gleefully disrupted by the souped-up banger playing loud music under the windows; the university has become ever-more instrumentalised as a research and training machine for the benefit of economic growth. Cultural studies brings a wider critical purpose, the idea 'there is an intellectual, ethical-moral purpose behind the production and distribution of knowledge that is directed towards the social and cultural wellbeing of a society, not just its economic development'. (184)

It is for this reason that Turner's chapter on 'convergence culture' and the 'creative industries' is so sharply pointed. He has dealt with the uncritical celebration of the utopian claims for convergence and new social media in an earlier book. Here again he highlights the intellectual paucity and sheer academic sloppiness of so much of this new wave of new media studies. But his ire is now chiefly directed at the claims that 'creative industries' represent a new paradigm for cultural studies. It is a polemic as controlled as it is mordant, exposing the complete collapse of any critical stance and its sell-out to the most instrumentalist economic agenda. In one of the most telling passages he exposes the kind of teaching consequent upon this, evacuating any disciplinary grounding in its grinding out of vocation-based training. For Turner this is not a revivification of the cultural studies project but its abdication. I would fully endorse this, but it might be worth reflecting on why this came about.

Cultural studies did not hot-wire a rusting car, they hitched a lift in one that was already revving and shining. It was the recognition that the explosion of popular 
culture from the 1950s onwards represented new exciting possibilities for social, cultural and political change which set it apart from the other cultural (and indeed non-cultural) disciplines. The mix of anger and satisfaction when the established disciplines dismissed as trivial what they knew to be the pulse of the zeitgeist gave cultural studies its energy and arrogance. Its mid-life crisis involves not just having to make an institutional living now that everybody else is now doing culture; it is also about popular culture itself. Turner and Grossberg are both keen to distance themselves from the idea that cultural studies just does popular cultural 'texts'. Turner comments on Stuart Hall's irate complaint that he could not bear to read another paper on The Sopranos:

This, I take it, accuses cultural studies of mistaking an analytic method for a political purpose; that is, textual analysis as being offered as ends in themselves rather than as modes of accessing deeper structural, cultural and political tendencies. Once again, this suggests cultural studies is becoming a performative or perhaps even an aesthetic, rather than a political practice. (173)

This is the nub of the problem. Certainly it is a corrective to the media image of the cultural studies dilettante performing abstruse deconstructions on the latest Madonna costume. More aptly it warns that we should not confuse personal enthusiasm with methodological rigour; rather than decoding signifiers we should be out doing serious research on 'deeper structural, cultural and political tendencies'. There is an anxiety here about the transformative possibilities of popular culture which cultural studies adopted to épater the sniffy academic establishment. Turner and, as we shall see, Grossberg (rightly in my view) argue that this was a real challenge to the powers that be and with a real impact on how academic work related to the wider society. But this valuation of popular culture as a site of democratic transformation could also fuel an anti-elitist ressentiment which, as in the work of John Hartley, results in an accommodation with the real powers that be at the expense of the 'experts' - which includes critical cultural studies. A globalised, capitalised media-saturated popular culture no longer needs cultural studies to give it legitimacy. Indeed, as it has moved closer to the centre of powerthink of London's media-politics-finance complex-cultural studies has sought out 'everyday life' as the site of the popular. Again understandable as a corrective to the 
concern with decoding the latest film/song/game-but it leaves the field for those new media and creative industry projects which equate that which gets the biggest audience with democracy, clicking buttons with 'participation' and critical expertise with elitism (Turner has yet to deal with the impending educational train-wreck that is 'entertainment studies'). The question hangs: is cultural studies too involved with its object to be capable of dealing critically with what popular culture has become, and on what grounds could it do so while avoiding the minotaur of Adorno it escaped so long ago?

There is a deeper anxiety. Australian cultural studies was a near neighbor of cultural policy studies, which shared many of its concerns: to be critical and selfaware but also to engage with power on its own terms, its own institutional terrain. There was nothing that could be done outside of this. One route from this position was towards the pragmatic instrumentalism Turner identifies with creative industries. Somewhere along the road, making the economic argument for culture as a strategic gambit to gain increased state funding became simply an end in itself. As Kafka wrote: 'He has found the Archimedean point but has used it against himself; evidently this is the condition of finding it.' Turner is certainly aware of the pitfalls involved in his pragmatic call to become an institutionalised (inter)discipline. But the deeper anxiety involves the impossibility of culture as critique per se.

In the 1990s Tony Bennett was already using Foucault to argue that the emancipatory space of 'culture' was in fact a constructed site of governmentality. This was fine while it was confined to accounts of the arts, museums and the enlightened humanist educational projects of the cultural elites. Indeed cultural studies took a lot of this on board as part of its vehement rejection of elite culture. Ian Hunter's work took this much further. He identified the transformative claims of cultural studies itself as part of the same tradition; that is, a transcendental critique in which intellectuals set culture against the instrumentalist procedures of the state. It is not just that popular culture could become a global enterprise, or that cultural populism could underpin a neoliberal project-critique itself was fatally compromised. It was a pose, a persona, in which intellectuals set themself over and above the real world. Not only was this aggrandisement a compensation for their irrelevance to power but it was parasitic on the state institutions they claimed to set themselves over. Hunter has spent the last thirty years exposing the pretentions of 
culture critique. If it was once a correction to cultural studies hubris (one that these books are fully willing to acknowledge), it is now deeply conservative and accommodating to the powers that be. Hunter's work is aimed right at the heart of cultural studies and the 'enlightened' university of which it wants to be a part.

There have been other ways of moving beyond culture critique and its concern with ideologies and texts that avoid conservatism and retain the possibility of a transformative project. Bruno Latour's version of actor network theory, Michel Callon and cultural economy are but two. They suggest a very different approach than encoding/decoding and a much more fluid, multiple, provisional notion of 'popular culture' involving complex assemblages of people and objects, affects and bodies, machines and lines of flight. It is to the challenge of re-asserting the relevance of cultural studies in this new context that Larry Grossberg sets himself. The book is three times longer and much more dense that Turner's. It addresses head on the full disciplinary spectrum ranged around the space of cultural studies. Three central chapters on economics, culture and politics represent a close engagement with the state of the field in contemporary social theory and a heroic attempt to assert the relevance of cultural studies within this new conceptual space. These are flanked by chapters on the conjuncture and modernity in which the project of cultural studies is redefined and tested against its disciplinary rivals. As with Turner this is not academic turf-staking but done in order to defend and extend the original project to contribute to social transformation.

The book is not for the faint hearted. Its call for rigour, respect for the protocols of disciplines and damn hard work are exemplified in a prose that is pretty unforgiving. It is not, as with Turner, 'media, popular culture and everyday life' which are at stake. For Grossberg these were the contingent or rather 'conjunctural' objects of cultural studies when it started out. Culture, and popular culture above all, were where it was at. That is, where the possibilities of change, of reimagining our collective future, our modernity was at. This, according to Grossberg, is no longer the case. There is now a new conjuncture in which different forces, different possibilities are to be sought out and made visible. This judgement as to the possibilities of the conjuncture is what Grossberg now identifies as the project of cultural studies-even though it might not always have known this. It is cultural studies' search for the political possibilities of any given conjuncture and the 
imperative (as with Turner) to range across disciplines to seek out the concepts necessary to its full articulation which marks it off as a distinct project.

Grossberg's articulation of this project is a hard slog. Gone are the Marxist references, apart from Gramsci as analyst of the conjuncture; it is Deleuze (and Guattari) who now dominate the conceptual machinery. Grossberg's reframing of cultural studies in the language of Deleuze can only be described as opaque, and his adoption of Deleuze's core concepts as if they were self-evidently true is reminiscent of cultural studies' long history of picking up and putting down the latest theoretical fad. But somewhere here there is an account of the conjuncture and how we might approach it which is very powerful. It gains power as we encounter the range of supportive and competing conceptual accounts presented in the core of the book. Reconstructing the conjuncture is complex. It recalls Benjamin's and Adorno's 'constellation', which similarly was a highly relational and provisional 'singularity'. Grossberg does not manage to distill this in the crystalline and mordant prose of these precursors, but then-as Joseph Heller was wont to answer when asked why he had not written a book as good as Catch 22-who has?

Facing the challenge of the conjuncture, reimagining what our modernity might be, is, then, what cultural studies does. The chapters on culture, economics and the final one on modernity are cogent and powerfully argued. They deal with the limits to culture and culture critique; but rather than root this-as with Hunter-in some primal Kantian move against the emergent modern state, Grossberg tries to reframe our 'euro-modernity' historically in the light of contemporary global change. The fixtures of culture and economy which have dominated Western critical thought since the eighteenth century float free; the Weberian 'disembeddedness' of these spheres is shown to be 'embedded' in our singular 'Euromodernity'. This in turn now opens up to a global stage onto which a whole new set of actors and possibilities are emerging. The shape of the 'modern' that cultural studies has sought to transform is changing again, and the claims of 'culture' no longer seem able to articulate this conjuncture. Cultural studies' interdiscplinarity was not, after all, to allow adequate attention to popular culture; it was to use any and all of these disciplines 'to provide a "better" understanding of "what's going on"':

First, cultural studies embraces a certain 'empirics' that is not defined by concepts of reflection or correspondence; rather it is part of a broader 
effort to define a 'new empiricism' in which knowledge is understood as an act within the world rather than a representation of the world. Second, cultural studies entails a certain ethic-political project insofar as it seeks to (re)constitute 'a context of possibilities' ... [Non Utopian] cultural studies has a more modest commitment to producing knowledge that illuminates the conjuncture and explores the possibilities of changing it. (57)

Two questions emerge from this retro-fitting of conjunctural analysis onto cultural studies. First, why should cultural studies be the privileged site from which these transformative possibilities might be identified? Do not other disciplineseconomics, politics or sociology, for example-have a purchase on the possibilities of the real as much as cultural studies? Turner's mission statement is the 'social and cultural well-being of society'-one more directly graspable than Grossberg's freefloating search for the possibilities of the conjuncture. But it is also one that many other disciplines-maybe, at their best, all disciplines-would claim. What gives cultural studies its sense of purpose, its specialness? Because it was radical in its youth? Because although it misdirected its attentions to the glittering objects of popular culture its intentions were always good and remain intact? Second, it may now be buckling down to hard empirical work on everyday life in all its mundanity; but why is this not cultural sociology (a discipline coming up strongly on the rails) or cultural geography or cultural economy or anthropology? In short what is cultural studies without 'culture' - those images, sounds, objects and words involved in 'mediation, signification, and significance' as one of Grossberg's chapters has it.

It seems to me that perhaps cultural studies needs to acknowledge its own 'other'. At the huge Crossroads conference in Hong Kong discussed extensively by Turner there were over seven hundred and fifty papers; not a single one discussed 'art'. I might suggest that the delegates to that conference would, in the main, provide the core audience for galleries, 'art films', theatre, dance, literature, music and so on in every city they live in and visit. Yet cultural studies does not, perhaps cannot, discuss art. Why? The postwar rise of popular culture might have been a conjunctural moment-I have no doubt it was-but cultural studies has been wedded to that moment in ways it has yet to acknowledge. Art is the 'other', that against which cultural studies defined itself. But as Ian Hunter constantly points out, cultural studies transposed the discourse of the aesthetic to popular culture. 
Turner's warnings about becoming 'performative or even aesthetic' rather than political marks this as a site of ultimate danger for cultural studies. But the danger of this in turn is that in order to avoid 'the aesthetic' one is forced to seek the popular free from 'the aesthetic'. If this once might have been called authenticity, it is now 'everyday life' or even 'encephalous culture'.

But the cultural studies garage band always had a near neighbour which it refused to acknowledge, at least not at work. What can we call it, the radical avantgarde or critical art theory, the new art history, political art practice? They all went to the same gigs and mooched around the same bars and clubs, but cultural studies knew that art was elitist and it was not where popular culture was at. Now that popular culture is not so straightforward cultural studies is abandoning the text, all texts, as aesthetic, and wants to do social research. It will find this tough going: that car has been hot-wired by somebody else (the Clare Quilty of cultural sociology perhaps). If-as a discipline called 'cultural studies' maybe should-it remains with 'media, popular culture and everyday life', it needs to look again at what has been happening in art theory and practice in the last thirty years. The 'autonomy of the aesthetic' so battered by cultural studies has hung on by its fingernails to become situated, relational, conditional, provisional, precarious. If cultural studies might be seen less as the abandonment of 'the aesthetic' and rather the expansion of its concerns into the realm of the popular (a charge Hunter wants to make the better to damn its project) then it could well learn from art theory's recent history. Looking back at its Golden Years the problem might not be its youthful enthusiasm but it being much more naive than art theory was about the aesthetic objects of its desire.

Maybe cultural studies should not attempt to be a sociology-cultural or otherwise-but engage with the new agenda of the assemblage of cultural possibilities represented by 'cultural economy', actor network theory, and so on. In this it would have to engage again with aesthetics; not just the images, sounds, objects and words but the project of aesthetics itself. If art and culture are sites of governmentality-what do we do about this? If we do not want to give to the state the absolute right-potentia-to produce the real, then what kind of counterproduction is possible? What is the proper space for 'culture' in this project? Surely this is where art theory-the best of it, including that wrapped up in new mediahas been for twenty years or so. If cultural studies no longer wishes to engage with 
the sensuous particularity of the text, and leaves the field of popular culture to an instrumental creative industries or an encephalous 'entertainment studies', then it should put its wild years in the garage and go out and get a proper job.

Justin O'Connor was director of Manchester Institute for Popular Culture for ten years unto 2006, when he joined the University of Leeds as chair of Cultural Industries. In 2008 he became professor in the Creative Industries Faculty, Queensland University of Technology. From January 2013 he will be chair of Communications and Cultural Economy at Monash University. 